\title{
Tick-Borne Pathogens in Ticks Collected from Wild Ungulates in North-Eastern Poland
}

\author{
Mirosław M. Michalski ${ }^{1}$ (D), Katarzyna Kubiak ${ }^{2}$ (D), Magdalena Szczotko ${ }^{3}$ (D) and Małgorzata Dmitryjuk ${ }^{3, *(D)}$ \\ 1 Department of Parasitology and Invasive Diseases, Faculty of Veterinary Medicine, University of Warmia and \\ Mazury in Olsztyn, 10-719 Olsztyn, Poland; michmm@uwm.edu.pl \\ 2 Department of Medical Biology, Collegium Medicum, School of Public Health, University of Warmia and \\ Mazury in Olsztyn, 10-561 Olsztyn, Poland; katarzyna.kubiak@uwm.edu.pl \\ 3 Department of Biochemistry, Faculty of Biology and Biotechnology, University of Warmia and Mazury in \\ Olsztyn, 10-719 Olsztyn, Poland; magdalena.szczotko@uwm.edu.pl \\ * Correspondence: m.dmit@uwm.edu.pl
}

check for updates

Citation: Michalski, M.M.; Kubiak, K.; Szczotko, M.; Dmitryjuk, M. Tick-Borne Pathogens in Ticks Collected from Wild Ungulates in North-Eastern Poland. Pathogens 2021, 10, 587. https://doi.org/10.3390/ pathogens10050587

Academic Editor: Consuelo Almazán

Received: 21 March 2021

Accepted: 7 May 2021

Published: 11 May 2021

Publisher's Note: MDPI stays neutral with regard to jurisdictional claims in published maps and institutional affiliations.

Copyright: (c) 2021 by the authors. Licensee MDPI, Basel, Switzerland. This article is an open access article distributed under the terms and conditions of the Creative Commons Attribution (CC BY) license (https:// creativecommons.org/licenses/by/ $4.0 /)$.
Abstract: This study was carried out in north-eastern Poland during two hunting seasons between 2018 and 2020. Ticks (Ixodes ricinus and Dermacentor reticulatus) were removed from wild cervids and boars and examined for the presence of Borrelia spirochetes and Rickettsiales members: Rickettsia spp. and Anaplasma phagocytophilum. The present study contributes to the knowledge of even-toed ungulates, which are an important reservoir of the above-mentioned pathogens and a potential source of infections for humans through ticks as vectors. Almost $40 \%$ of the collected ticks (191 out of 484) were infected with the following pathogens: 3.3\% with Borrelia spp., 19.2\% with A. phagocytophilum and $26.9 \%$ with Rickettsia spp. Only the ticks collected from cervids carried Borrelia. Typing of the species DNA confirmed the presence of B. afzelii, B. garinii, B. lusitaniae and B. miyamotoi. An analysis of Rickettsia spp. sequences using the GenBank data revealed the presence of $R$. helvetica, $R$. raoultii and $R$. monacensis. Monoinfections (79.1\%) dominated over co-infections (20.9\%). Among co-infections, the most frequent was A. phagocytophilum/Rickettsia spp. (70\%), however co-infections, including B. afzelii/A. phagocytophilum, B. afzelii/Rickettsia spp., B. miyamotoi/A. phagocytophilum and B. afzelii/B. garinii/B. lusitaniae, were also noted. Significant differences were observed in the affinity of some pathogens to their vectors. Thus, Borrelia spp. and A. phagocytophilum were more frequently detected in I. ricinus (5.3\% and $23.1 \%$ ) than in D. reticulatus (1.2\% and $15.3 \%)$. Infection frequency with Rickettsia spp. was similar (approximately 25-29\%) in both tick species. The prevalence of $A$. phagocytophilum and Rickettsia spp. in ticks removed from cervids was $19.8 \%$ and $27.1 \%$, and in ticks from wild boars it was $13.3 \%$ and $24.4 \%$, respectively.

Keywords: Borrelia burgdorferi sensu lato; Borrelia miyamotoi; Anaplasma phagocytophilum; Rickettsia spp.; tick-borne pathogens; Ixodes ricinus; Dermacentor reticulatus; wild mammals

\section{Introduction}

Understanding the interrelationship between wildlife, livestock and public health presents a great challenge. Man-made landscapes, a mix of natural habitats and farmland, modify the abundance, composition and cohesion of populations and allow for contact between wildlife, livestock and humans. This, in turn, favors pathogen circulation among many hosts [1,2]. Wild animals, even at very low population densities, are important drivers of the abundance of ticks, as they promote their reproduction and passively spread potentially infected ticks. Viruses, bacteria and protozoa in ticks may be pathogenic to both humans and domesticated animals [3,4]. Therefore, the screening of wild animals, such as cervids and wild boars, is essential for revealing the relationship between sylvatic and domestic pathogen cycles. It provides basic information for a risk assessment of animal and human health in a given region [5]. Human interference in the natural ecosystems changes 
the populations of wild animals, as well as of ticks and the pathogens they transmit. The risk of tick-borne pathogen (TBP) transmission is increasing all over the world [6,7].

Serious diseases, including Lyme borreliosis (LB), anaplasmosis and tick-borne rickettsioses are caused by various bacterial species from the genera Borrelia, Anaplasma and Rickettsia. Recently, new pathogens are appearing, such as the spirochete B. miyamotoi that causes a relapsing fever "Borrelia miyamotoi disease" [8-10]. Different Borrelia species (or genotypes) cause varying LB clinical symptoms. Every year, the LB incidence in northeastern Poland is almost twice the level of the rest of Poland [11]. In general, in Europe, small and medium-sized rodents, several species of birds, reptiles and insectivores are considered as competent reservoir hosts, i.e., those that may be infected with Borrelia and transmit the pathogen to uninfected ticks. In contrast, large wild and domestic ruminants (e.g., deer and sheep) are considered incompetent reservoirs since ticks feeding on them do not transmit Borrelia. However, cervids are an important source of blood in all stages of tick development and ticks may transmit spirochetes to each other when they feed very closely on an incompetent host [12].

Another very common tick-transmitted pathogen, A. phagocytophilum, causes human granulocytic anaplasmosis (HGA). Wild animals play a significant role in the prevalence and transmission of this pathogen. Scientific evidence has been accumulating on wildlife acting as a reservoir and an amplification "hub" of human or domestic animal diseases $[13,14]$. In Europe, cervids are suspected of being the main reservoir of $A$. phagocytophilum, with infection rates as high as up to 90\% [2,15-20]. Variants detected in roe deer have been shown to be non-pathogenic to humans, dogs, horses and domestic ruminants, but variants detected in red deer and wild boars may cause HGA [17-20]. Cervids seem to play a more important role in the circulation of the A. phagocytophilum genetic variants pathogenic to humans and/or domestic and companion animals than wild boars [21].

The pathogenic potential of the genus Rickettsia is less clear. Among several Rickettsia classifications, the most common system uses four groups: spotted fever group (SFG), typhus group, the Rickettsia bellii group and the Rickettsia canadensis group [22]. In central Europe, the following five Rickettsia species have been detected in ticks: $R$. slovaca, $R$. raoultii, $R$. helvetica, R. monacensis and Candidatus Rickettsia mendelii [9]. R. slovaca and $R$. raoultii cause tick-borne lymphadenopathy (TIBOLA) and DEBONEL lymphadenopathy (Dermacentor-borne necrosis erythema). In contrast, although the pathogenic potential of $R$. helvetica and $R$. monacensis is controversial, they may cause a mild illness similar to spotted-fever-like disease [22]. Many Rickettsiae are transmitted vertically among ticks, which suggests that ticks are not only vectors but also reservoirs of rickettsiae in nature. However, these pathogens were also detected in numerous vertebrate hosts such as birds, reptiles and mammals [22,23].

This study aimed to compare the prevalence of particular tick-transmitted Borrelia spirochetes and Rickettsiales members: Rickettsia spp. and A. phagocytophilum in I. ricinus and $D$. reticulatus ticks removed from wild ungulates (cervids and boars) in north-eastern Poland during two hunting seasons between 2018 and 2020.

\section{Results}

\subsection{Tick Collection}

Among the 484 ticks collected from cervids (red deer, Cervus elaphus and roe deer, Capreolus capreolus) and wild boars (Sus scrofa) from three subregions (western, central and eastern) of northeastern Poland between 2018-2020, I. ricinus $(n=242,50 \%)$ and D. reticulatus $(n=242,50 \%)$ were identified (Table 1$)$. A total of 242 of I. ricinus were removed from cervids (208 females, 33 males and 1 nymph) $(n=220,91 \%)$ and wild boars ( $n=22,9 \%)$. Out of 242 D. reticulatus (50 females and 192 males) $90 \%(n=219)$ were collected from cervids and $10 \%(n=23)$ from wild boars. In the east, the most forested subregion of north-eastern Poland, $72.7 \%$ of the tested tick specimens originated from hunted wild ungulates. From western and central subregions $15.3 \%$ and $12 \%$ of all ticks were collected, respectively. 
Table 1. Infection rates of ticks removed from wild ungulates in north-eastern Poland.

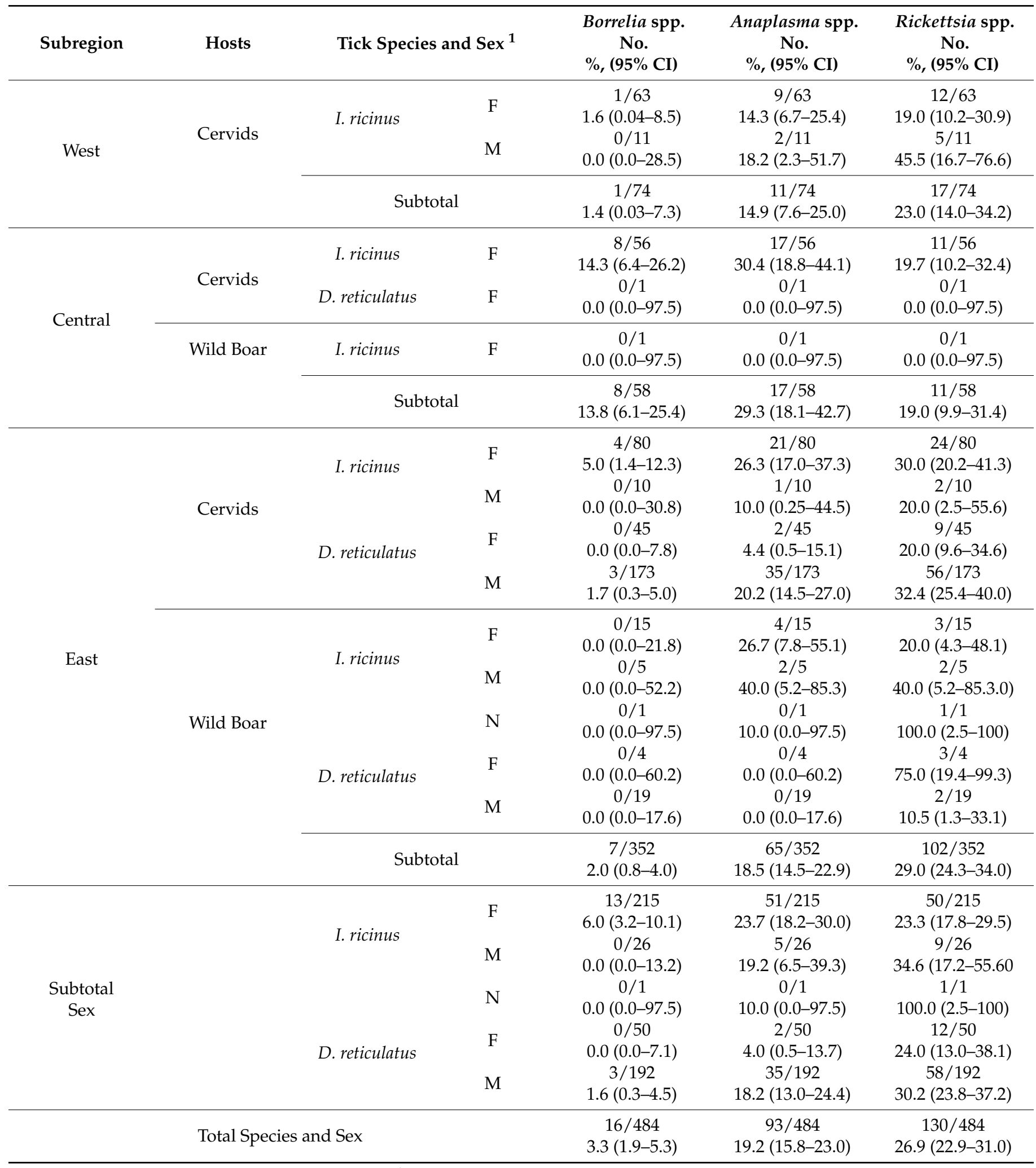




\subsection{Prevalence and Diversity of Pathogens}

The DNA of one, two or three tick-borne microorganisms was detected in 39.5\% (191/484) of tick genomic DNA isolates. Overall, the prevalence of examined pathogens was $3.3 \%(n=16)$ for Borrelia spp., $19.2 \%(n=93)$ for A. phagocytophilum and $26.9 \%(n=130)$ for Rickettsia spp. (Table 1). Among positive PCR products, 54\% (129/239) originated from I. ricinus and $46 \%(110 / 239)$ from $D$. reticulatus. The highest percentage of ticks infected with bacteria Borrelia spp. and A. phagocytophilum was recorded in the central subregion of northeastern Poland $(8 / 58,13.8 \%$ and $17 / 58,29.3 \%$, respectively). Infections of Rickettsia spp. $(29.0 \%, 102 / 352)$ were the most frequent in ticks feeding on wild ungulates from the eastern subregion (Table 1).

\subsubsection{Borrelia spp.}

A fragment of the flaB gene of Borrelia spp. was detected in $16(3.3 \%)$ tick isolates, collected only from cervids $(16 / 439,3.6 \%)$ (Table 1$)$. Most of them $(13 / 16,81.3 \%)$ were identified in I. ricinus. The I. ricinus-infection rate $(13 / 242,5.4 \%)$ was significantly higher $\left(\chi^{2}=6.4, p<0.05\right)$ than that in $D$. reticulatus $(3 / 242,1.2 \%)$. A comparison indicates that $I$. ricinus females harbored Borrelia spp. more often $(6.0 \%, 13 / 215)$ (Table 1$)$ than D. reticulatus males, as well $(1.6 \%, 3 / 192)$ (I. ricinus females vs D. reticulatus males: $\left.\chi^{2}=5.4, p<0.05\right)$. I. ricinus male and $D$. reticulatus female were not infected with Borrelia spirochetes.Species typing performed on the basis of RFLP patterns revealed the presence of DNA of B. afzelii, B. garinii, B. lusitaniae and B. miyamotoi. DNA of B. afzelii, the most dominant species, was detected in 11 samples from $I$. ricinus and in three samples from $D$. reticulatus. In one DNA sample from I. ricinus, B. afzelii was in co-infection with B. garinii and B. lusitaniae. B. miyamotoi was found in only one I. ricinus female tick $(1 / 484,0.2 \%)$. The highest percentage of ticks infected with the Borrelia genus derived from I. ricinus was recorded in the central subregion of north-eastern Poland $\left(8 / 58,13.8 \%\right.$ ) (Table 1) (central vs west: $\chi^{2}=6.7$; central vs east: $\left.\chi^{2}=16.5 ; p<0.05\right)$.

Three randomly selected PCR products identified by RFLP as B. afzelii and B. miyamoto $i$ were sequenced. Sequences of B. afzelii (GenBank: MW595226-595227) were identical and showed $100 \%$ nucleotide identity with those of the BO23 and K78 strains, which are pathogenic to humans (GenBank: CP018262, CP009058) (Figure 1). These sequences were also $100 \%$ identical to B. afzelii sequences derived from Ixodes ticks questing (GenBank: MF150047) and feeding on fox (Vulpes vulpes) (GenBank: MG944962) and from the blood of rodent Apodemus agrarius (GenBank: KY626318) in Poland. The PCR product from I. ricinus removed from red deer skin identified as B. miyamotoi (GenBank: MW59528) was grouped with the sequence of isolate Mos- 80 of B. miyamotoi from Russian I. ricinus designated as European-type [24,25]. On the phylogram, the obtained B. miyamotoi sequence clustered with other sequences derived from questing I. ricinus from the Czech Republic (GenBank: CP046389), from the Netherlands (GenBank: CP044783), and from Poland (GenBank: KX646199) (Figure 1).

\subsubsection{Anaplasma phagocytophilum}

A. phagocythophilum DNA was identified in $19.2 \%(93 / 484)$ of tick DNA samples. The infection rate was significantly higher $\left(\chi^{2}=4.8, p<0.05\right)$ in I. ricinus $(56 / 242,23.1 \%)$ than in D. reticulatus (37/242, 15.3\%) (Table 1$)$. Anaplasma DNA was more frequently detected $\left(\chi^{2}=10.4, p<0.05\right)$ in I. ricinus females $(23.7 \%, 51 / 215)$ in comparison with females of $D$. reticulatus $(4 \%, 2 / 50)$. The percentage of infected I. ricinus and D. reticulatus males was similar $\left(\chi^{2}=0.02, p=0.9015\right)$ and reached $19.2 \%(5 / 26)$ and $18.2 \%(35 / 192)$, respectively. The highest percentage of ticks infected with A. phagocytphilum was detected in the central subregion of north-eastern Poland $\left(17 / 58,29.3 \%\right.$ ) (Table 1) (central vs. west: $\chi^{2}=4.1$, $p<0.05$; central vs. east: $\chi^{2}=3.7, p=0.06$ ). 


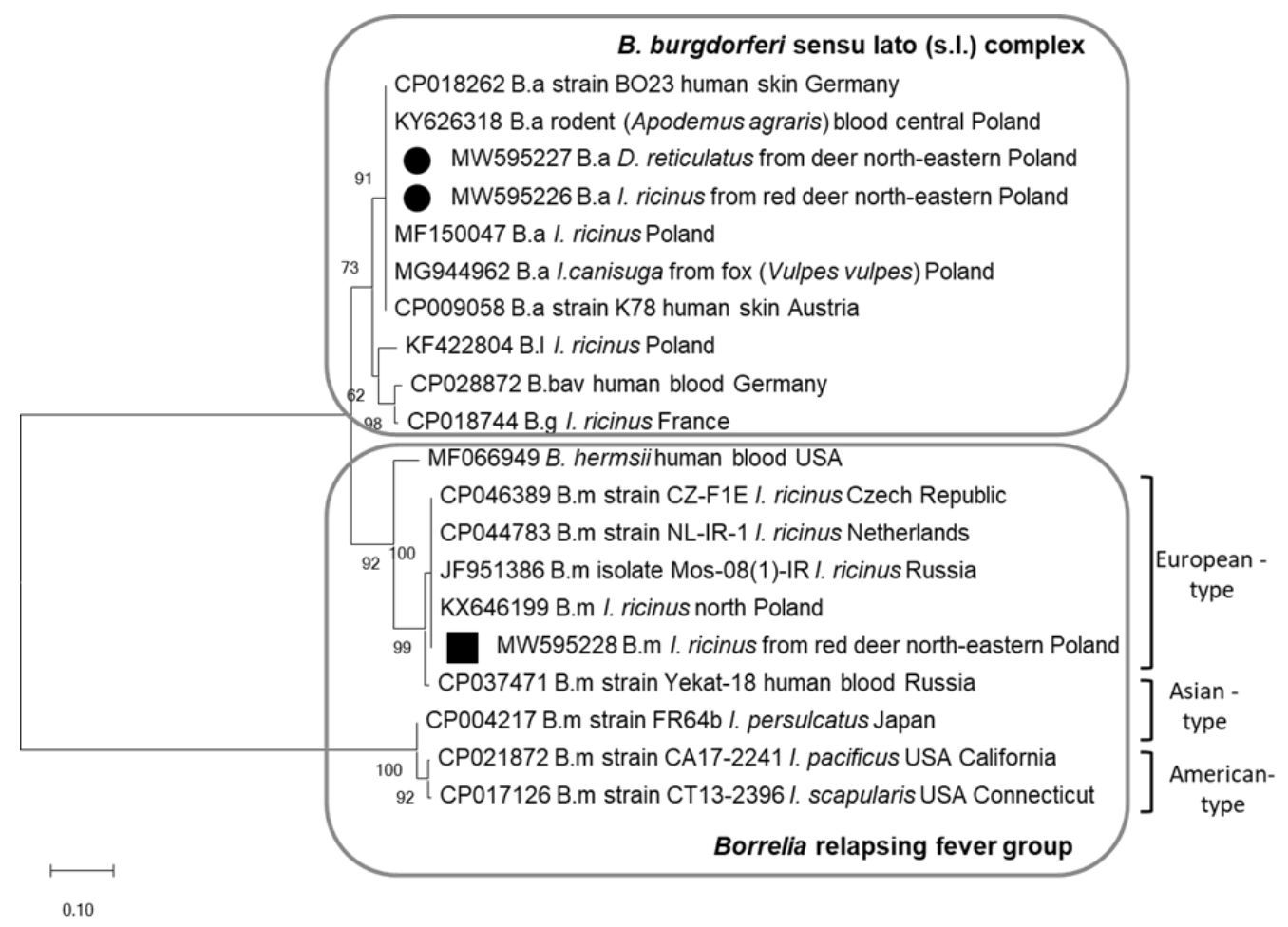

Figure 1. Molecular relationships between Borrelia species identified in the study and accession numbers from GenBank, based on the sequences of the flaB gene. Phylogram constructed using the neighbor-joining method and the Maximum Composite Likelihood as a distance method. Numbers at the tree nodes indicate the percent of bootstrap value from 1000 replicates. The tree is drawn to scale, with branch lengths measured in the number of base substitutions per site. The analyses were conducted in MEGA X. The sequences obtained in this study were labelled with black symbols. Abbreviations: B.a-B. afzelii, B.g-B. garinii, B.1-B. lusitaniae, B.bav-B. bavariensis, B.m-B. miyamotoi.

Five positive PCR products amplified from DNA samples of different species of ticks collected from different hosts were sequenced and registered in GenBank under accession numbers MW591521-591525. All of them were identical and showed $100 \%$ similarity to the sequence of Norway variant2 of A. phagocytophilum (GenBank: CP015376) derived from sheep, isolate P13016 from the blood of a patient in Austria (GenBank: KT454992), and sequences from the blood of game animals in Portugal (GenBank: LC126876) and Romania (GenBank: KT351866).

\subsubsection{Rickettsia spp.}

Rickettsia spp. was detected in $26.9 \%(130 / 484)$ of analyzed tick DNA samples. There were no significant differences in infection rate $\left(\chi^{2}=1.05, p=0.31\right)$ between $D$. reticulatus $(70 / 242,28.9 \%)$ and I. ricinus $(60 / 242,24.8 \%)$ (Table 1$)$. The highest percentage of infected ticks was recorded among males of both species, i.e., 34.6\% (9/26) for I. ricinus and $30.2 \%$ $(58 / 192)$ for $D$. reticulatus $\left(\chi^{2}=0.2, p=0.65\right)$. Females of both tick species displayed similar levels $\left(\chi^{2}=0.01, p=0.91\right)$ of Rickettsia spp. infection, i.e., $23.3 \%(50 / 215)$ and $24 \%(12 / 50)$, respectively (Table 1). The highest Rickettsia spp. prevalence was noted in the eastern subregion of northeastern Poland $(29.0 \%, 102 / 352)$ (Table 1$)$. However, no statistically significant differences were noted (east vs central: $\chi^{2}=2.2, p=0.13$; east vs west: $\chi^{2}=0.9$, $p=0.34$ ).

To identify the Rickettsia species, ten amplicons of the gltA gene fragment (769 bp) were sequenced. Sequenced amplicons were derived from diverse tick species collected from different hosts. Comparison with the data registered in the GenBank revealed the presence of $R$. helvetica $(n=6), R$. raoultii $(n=3)$ and $R$. monacensis $(n=1)$. Four $R$. helvetica sequences (GenBank: MW595234-595237) derived from I. ricinus were collected from red deer, roe deer and wild boar and two (GenBank: MW595232-595233) were derived from 
$D$. reticulatus feeding on deer and wild boar. All obtained $R$. helvetica sequences were identical and clustered with the $R$. helvetica strain C9P9 (GenBank: U59723) and sequences derived from questing I. ricinus from Poland (GenBank: MH018961-78) (Figure 2). Three sequences (MW595229-595231) derived from I. riciuns and D. reticulatus feeding on deer were identical with the $R$. raoultii strain IM16 isolated in a human sample from China (GenBank: CP019435) and from questing D. reticulatus in Poland (GenBank: KT277489) (Figure 2). The remaining single Rickettsia sequence (MW595238) obtained from I. ricinus collected from deer displayed $100 \%$ identity with gltA sequences of the $R$. monacensis strain IrR/Munich from Germany (GenBank: LN794217) and from questing I. ricinus ticks from Poland (MH018979-82).

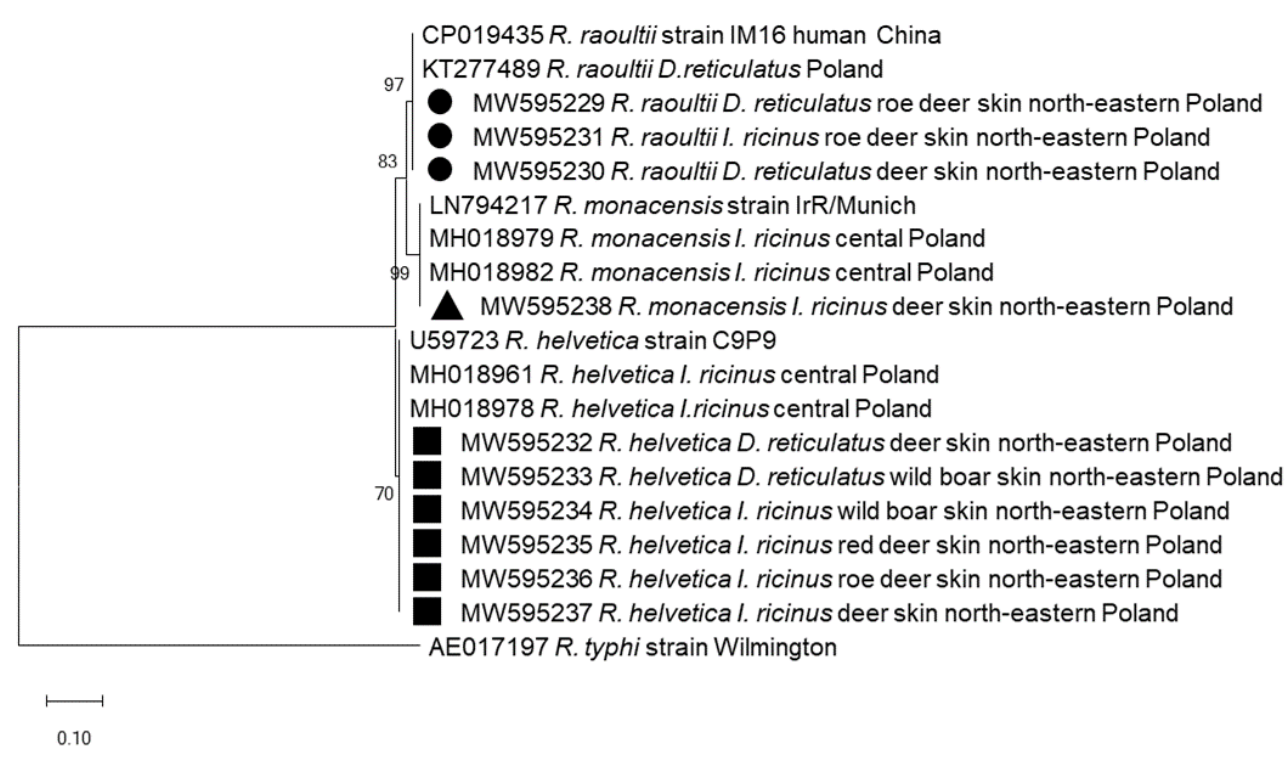

Figure 2. Molecular relationships between Rickettsia species identified in the study and accessions from GenBank, based on the sequences of the gltA gene of Rickettsia. Phylogram constructed using the neighbor-joining method and the Maximum Composite Likelihood as a distance method. Numbers at the tree nodes indicate the percent of bootstrap value from 1000 replicates. The tree is drawn to scale, with branch lengths measured in the number of base substitutions per site. The analyses were conducted in MEGA X. The sequences obtained in this study are labelled with black symbols.

\subsubsection{Borrelia spp., Anaplasma phagocytophilum and Rickettsia spp. Co-Infections}

Monoinfections were identified in $79.1 \%(151 / 191)$ of tick DNA samples that were PCR-positive for microorganisms (monoinfections vs co-infections: $\chi^{2}=129, p<0.05$ ). Among monoinfections, the most numerous were Rickettsia spp. $(96 / 151,63.6 \%)$ and $A$. phagocytophilum $(52 / 151,34.4 \%)$, while the least numerous were B. afzelii monoinfections $(3 / 151,2.0 \%)\left(\right.$ Rickettsia spp. vs A. phagocytophilum: $\chi^{2}=25.7, p<0.05$; Rickettsia spp. vs $B$. afzelii: $\chi^{2}=122.9, p<0.05$ ).

Co-infections of at least two pathogens were recognized in $20.9 \%(40 / 191)$ of positive samples (Table 2). The most frequently recorded co-infections were $A$. phagocytophilum/Rickettsia spp. (28/40, 70\%, 95\% CI: 53.4-83.4\%). It was the only co-infection recorded in all three subregions.

However, in the western subregion, results indicated a moderated positivity to $A$. phagocytophilum and Rickettsia spp., in correlation with each other $(r=0.4, p<0.01)$. In the eastern direction positive results were more randomly distributed (central subregion: $r=0.08, p=0.58$; eastern subregion: $r=0.01, p=0.91$ ).

This tendency was not observed for other double co-infections (Table 2). Four cases of co-infection were recorded for B. afzelii/A. phagocytophilum (4/40, 10\%, 95\% CI: 2.8-23.6\%), and B. afzelii/Rickettsia spp. (4/40,10\%, 95\% CI: 2.8-23.6\%). DNA of all three microorganism was detected in two ticks (2/40,5\%,95\% CI: 0.6-16.9). One co-infection was recorded with B. miyamotoi/A. phagocytophilum (1/40, 2.5\%, 95\% CI: 0.06-13.1\%). One co-infection 
with three genotypes within the B. burgdorferii s.l. complex, i.e., B. afzelii/B.garinii/B. lusitaniae, was also recorded (1/40, 2.5\%, 95\% CI: 0.06-13.1\%) (Table 2).

Table 2. Co-infection rates of ticks removed from wild mammals in the hunting subregions of northeastern Poland, with the pathogens of the genera Borrelia, Anaplasma and Rickettsia.

\begin{tabular}{|c|c|c|c|c|c|c|c|c|}
\hline \multirow[t]{2}{*}{ Subregion } & \multirow{2}{*}{ Host $^{1}$} & \multirow{2}{*}{$\begin{array}{c}\text { Tick } \\
\text { Species }^{2}\end{array}$} & \multicolumn{4}{|c|}{ Double Co-Infections No. Pearson's Correlation for Subregions } & \multicolumn{2}{|c|}{$\begin{array}{c}\text { Triple } \\
\text { Co-Infections No. }\end{array}$} \\
\hline & & & $A p / R$ & $B a / A p$ & $B a / R$ & $B m / A p$ & $B a / A p / R$ & $\mathrm{Ba} / \mathrm{Bg} / \mathrm{Bl}$ \\
\hline West & $\mathrm{C}$ & Ir & $\begin{array}{c}7 / 74 \\
r=0.4, p<0.01^{3}\end{array}$ & $0 / 74$ & $0 / 74$ & $0 / 74$ & $0 / 74$ & $0 / 74$ \\
\hline \multirow{3}{*}{ Central } & $\mathrm{C}$ & $\begin{array}{l}I r \\
D r\end{array}$ & $\begin{array}{c}4 / 56 \\
0 / 1\end{array}$ & $\begin{array}{c}0 / 56 \\
0 / 1\end{array}$ & $\begin{array}{c}2 / 56 \\
0 / 1\end{array}$ & $\begin{array}{c}1 / 56 \\
0 / 1\end{array}$ & $\begin{array}{c}2 / 56 \\
0 / 1\end{array}$ & $\begin{array}{c}1 / 56 \\
0 / 1\end{array}$ \\
\hline & WB & Ir & $0 / 1$ & $0 / 1$ & $0 / 1$ & $0 / 1$ & $0 / 1$ & $0 / 1$ \\
\hline & \multicolumn{2}{|c|}{ Subtotal Central } & $\begin{array}{c}4 / 58 \\
r=0.08, p=0.58\end{array}$ & $0 / 58$ & $\begin{array}{c}2 / 58 \\
r=0.06, p=0.65\end{array}$ & $\begin{array}{c}1 / 58 \\
r=0.21, p=0.12\end{array}$ & $2 / 58$ & $1 / 58$ \\
\hline \multirow{3}{*}{ East } & $\mathrm{C}$ & $\begin{array}{l}I r \\
D r\end{array}$ & $\begin{array}{l}7 / 90 \\
9 / 218\end{array}$ & $\begin{array}{c}2 / 90 \\
2 / 218\end{array}$ & $\begin{array}{c}1 / 90 \\
1 / 218\end{array}$ & $\begin{array}{c}0 / 90 \\
0 / 218\end{array}$ & $\begin{array}{c}0 / 90 \\
0 / 218\end{array}$ & $\begin{array}{c}0 / 90 \\
0 / 218\end{array}$ \\
\hline & WB & $\begin{array}{l}\text { Ir } \\
D r\end{array}$ & $\begin{array}{l}1 / 21 \\
0 / 23\end{array}$ & $\begin{array}{l}0 / 21 \\
0 / 23\end{array}$ & $\begin{array}{l}0 / 21 \\
0 / 23\end{array}$ & $\begin{array}{l}0 / 21 \\
0 / 23\end{array}$ & $\begin{array}{l}0 / 21 \\
0 / 23\end{array}$ & $\begin{array}{l}0 / 21 \\
0 / 23\end{array}$ \\
\hline & \multicolumn{2}{|c|}{ Subtotal East } & $\begin{array}{c}17 / 352 \\
r=0.01, p=0.91\end{array}$ & $r=\begin{array}{c}4 / 352 \\
0.14, p< \\
0.01\end{array}$ & $\begin{array}{c}2 / 352 \\
r=-0.0004, p=1\end{array}$ & $0 / 352$ & $0 / 352$ & $0 / 352$ \\
\hline
\end{tabular}

${ }^{1} \mathrm{C}$-cervids, WB-wild boar; ${ }^{2} \mathrm{Ir}$-Ixodes ricinus, Dr-Dermacentor reticulatus; Ap-Anaplasma phagocytophilum, $\mathrm{R}$-Rickettsia spp., BaBorrelia afzelii, $\mathrm{Bm}$-Borrelia miyamotoi, Bg—Borrelia garinii; $\mathrm{Bl}$-Borrelia lusitaniae; ${ }^{3} \mathrm{r}$-Pearson's correlation coefficient.

More co-infections were detected in I. ricinus (28/40, 70.0\%, 95\% CI: 53.5-83.4) than in D. reticulatus ticks $(12 / 40,30.0 \%, 95 \%$ CI: $16.6-46.5)$ (Table 2). The result was significant at $p<0.5\left(\chi^{2}=12.8, p<0.05\right)$. Moreover, there were no statistically significant differences for the occurrence of mono-infections in both species of ticks $\left(\chi^{2}=0.33, p=0.56\right)$.

\subsection{Comparison of Infection in Ticks from Different Hosts}

All 16 cases of Borrelia spp. were detected in I. ricinus and D. reticulatus collected from cervids (16/439, 3.6\%, 95\% CI: 2.1-5.8\%). Ticks removed from wild boars were not infected with Borrelia spirochetes. The prevalence of A. phagocytophilum and Rickettsia spp. in ticks feeding on cervids was $19.8 \%$ (87/439, 95\% CI: $16.2-23.9 \%)$ and $27.1 \%(119 / 439,95 \%$ CI: 23.0-31.5), while in ticks feeding on wild boars it was $13.3 \%$ (6/45, 95\% CI: $5.0-26.8 \%)$ and $24.4 \%(11 / 45,95 \%$ CI: $12.9-39.5)$, respectively. For both pathogens, infection rate was similar (for A. phagocytophilum: $\chi^{2}=1.1, p=0.29$; for Rickettsia spp. $\chi^{2}=0.1, p=0.7$ ). The infection rate in ticks removed from cervids and wild boars was also similar $\left(\chi^{2}=0.3\right.$, $p=0.57)$.

\section{Discussion}

Depending on the daily rhythm of foraging and resting, and on the density of vegetation, free-living ungulates can cover long distances each day. This behavior makes them a readily accessible host for ticks which, in turn, are a reservoir of serious pathogens. Thus, cervids and boars contribute to the circulation of TBPs in the wilderness [26]. In the presented study, DNA of Borrelia spp., A. phagocytophilum and Rickettsia spp. was identified in ticks collected from ungulates hunted during two seasons in northeastern Poland.

The ticks collected in the current study represented two species: I. ricinus and D. reticulatus, which is similar to studies on ticks isolated from dairy cows in the eastern Poland [27]. From an epidemiological point of view, I. ricinus tick has greater importance than $D$. reticulatus. Although the D. reticulatus can transmit Babesia canis, bacteria of the genera Rickettsia and Anaplasma, or tick-borne encephalitis virus to the host [28], the 
involvement of this tick as a vector of Borrelia spirochetes is still unproven. Borrelia DNA in this tick species has already been reported. It should be noted that the region of northeastern Poland is considered typical of D. reticulatus and should be treated as a contiguous area of eastern populations of this tick [29].

Only limited data are available on Borrelia spirochete in ticks isolated from wild animals [6,30-33]. In the current study, the Borrelia infection rate was low, i.e., 3.3\%, which is in line with the $3.4 \%$ reported from Spain [32]. In north-eastern Poland, for comparison, $31.6 \%$ of ticks isolated from dogs in urban areas, and $27.4 \%$ of questing ticks were infected with Borrelia [11,34]. The low level of Borrelia in the ticks found on wild mammals may be due to natural host immunity, involving an alternative complement activation in ungulate blood. These complements effectively eliminate Borrelia spp. from ungulates, and even from their ticks. Ticks feeding on red deer and wild boars have been shown to lose Borrelia infections [30]. Most ticks in this analysis were infected with B. afzelii, which is similar to the results reported by Seo et al. [6]. In Spain, B. garinii, B. valaisiana, B. lusitaniae, and B. afzelii were the most prevalent species in ticks removed from roe deer [32]. In the present study, B. garinii and B. lusitaniae were also detected in fully-engorged I. ricinus females isolated from red deer in the central part of north-eastern Poland (Bartoszyce hunting region), but those species occurred in a triple co-infection with $B$. afzelii. This study also confirmed the presence of B. miyamotoi, classified as a relapsing fever Borrelia. This indicates the constant presence of this pathogen in I. ricinus in Poland [10,11,35-37]. B. miyamotoi was also identified in two males and one nymph caught on a roe deer in Spain [32]. These results show that although deer may have limited utility as an indicator of the presence of Borrelia spirochetes, they provide for a good estimate of the species diversity of these TBPs in Europe. The contribution of I. ricinus to the spread of Borrelia is undeniable. Moreover, the present study detected Borrelia DNA in three D. reticulatus ticks. This seems surprising from the point of view of the existence of spirochete-eliminating mechanisms in ungulates and the presence of defensins in the salivary glands of D. reticulatus, which are attributed the role of specific antibiotics [38].

Ticks feeding on wild even-toed ungulates which were examined in this study were infected with $A$. phagocytophilum in a similar percentage to ticks isolated from wild cervids in west-central Poland. Both studies are also linked by the fact that female I. ricinus were infected more frequently with A. phagocythophilum than male ticks of this species [39]. In other studies in Poland, the rate of tick infection with A. phagocytopilum depends on the region and host species. In north-western Poland, ticks feeding on wild game were not infected with $A$. phagocytophilum [40], while in other studies from this region, ticks collected from roe deer and red deer were infected almost half as often as in the current research [15]. This study also suggests that at least in north-eastern Poland, wild mammals are probably an important reservoir of human anaplasmosis pathogen, i.e., $A$. phagocythophilum. To fully confirm this, however, it would be necessary to study the genetic variants of the pathogen. The obtained results are in agreement with previously published data in Europe [15,16,19,39,41-44] based on which rather convincing molecular evidence was presented last year on ticks isolated from urban dogs [34].

The present paper reports on the presence of $R$. helvetica, $R$. monacensis, and $R$. raoultii in ticks isolated from wild ungulates. The first two species have already been found in Poland in questing ticks and in ticks removed from Shetland ponies, cats, dogs, bats, and rodents [23,31,45-47]. R. helvetica caused only relatively mild symptoms in humans: a headache, sometimes a rash and an inoculation eschar. Infection with $R$. monacensis has a similar course, but in addition to inoculation eschar and a rash on hands and soles, it may cause flu-like symptoms and fever [22]. R. raoultii is similar to $R$. slovaca since it causes a more severe disease than the previous two species, i.e., TIBOLA or DEBONEL [22]. In Poland to date, $R$. raoultii has been identified mainly in $D$. reticulatus ticks $[45,48-53]$. This study also identified $R$. raoultii in I. ricinus, similar to Chmielewski et al. [45] who detected this pathogen in I. ricinus ticks collected from dogs and cats in central Poland. 
A quantitative analysis of the data indicates that wild even-toed ungulates, along with other mammals, are important reservoirs of pathogens belonging to the SFG rickettsiae. In this study, $26.8 \%$ of ticks collected from wild ungulates were infected with SFG. For comparison, in 2015, 44\% of adult questing ticks examined in the same area were infected [49]. In other studies in Poland, the degree of tick infection by Rickettsia spp. oscillates widely between $1.3 \%$ and $53 \%$ in questing ticks $[23,45,48,50-52,54,55]$ and in ticks removed from different species of mammals, the tick infection rate ranges from $5.2 \%$ to $37.5 \%[31,46,47,56]$. The present results are similar to those obtained in Germany, where approximately $23 \%$ of Rickettsia DNA-positive samples were found in ticks isolated from wild animals [57]. In addition, in this study, mono-infections account for nearly $80 \%$ of positive cases. However, among co-infections, $70 \%$ were the combination of A. phagocytophilum/Rickettsia spp. In the present study, a distinct west-east gradient emerges in the occurrence of this co-infection. While in the western region A. phagocytophilum and Rickettsia spp. are clearly positively correlated, in the regions towards the east they are increasingly randomly distributed. This might be connected with the increasing representation of $D$. reticulatus towards the east, which is endemic for this tick species, or with a greater dispersion of sampling sites in the east of the region. The frequent coexistence of both pathogens along with their relatively high prevalence in ticks studied in the current study, confirms that cervids and wild boars are important reservoirs of Rickettsiales bacteria.

In summary, it should be emphasized that although cervids have limited utility as an indicator of the presence of Borrelia spirochetes, they may provide a good estimate of the species diversity of these TBPs in Europe. In northeastern Poland, wild even-toed ungulates, along with other mammals, are reservoirs of pathogens belonging to SFG rickettsiae and another member of Rickettsiales: A. phagocytophilum.

\section{Materials and Methods}

\subsection{Study Area, Tick Collection and Species Identification}

Ticks were collected from red deer (C. elaphus), roe deer (C. capreolus) and wild boar (S. scrofa) during two consecutive legal hunting seasons (September-April) between 2018-2020. The hunted animals came from nine hunting districts located in the west (Ostróda), central (Bartoszyce, Reszel, Gietrzwałd, Olsztynek) and east (Kowale Oleckie, Giżycko, Pisz, Bielsk Podlaski) subregions in northeastern Poland (Warmia and Mazury province). The hunters isolated one to seven ticks per animal and then preserved the collected ticks in $70 \%$ ethanol. In the laboratory, the species, developmental stage and sex of the ticks were identified using taxonomic keys [58].

\subsection{DNA Extraction}

Before DNA extraction, ticks preserved in $70 \%$ ethanol were dried. Full-engorged ticks were bisected along their longitudinal axis to provide the optimal weight of each sample. Anterior parts of fully-engorged or whole non- and slightly-engorged ticks were separately crushed using a sterile mortar. The material was then transferred to $2 \mathrm{~mL}$ tubes filled with lysis buffer (A\&A Biotechnology, Gdynia, Poland) and incubated for $2 \mathrm{~h}$ at $50{ }^{\circ} \mathrm{C}$. After lysis, total DNA was extracted according to the manufacturer's protocol (Micro AX Tissue Gravity, A\&A Biotechnology, Gdynia, Poland) and stored at $-70^{\circ} \mathrm{C}$ until further analyses.

\subsection{Pathogens DNA Detection}

\subsubsection{Borrelia Species}

The presence of Borrelia DNA in ticks was confirmed by the nested polymerase chain reaction method using two sets of primers specific to the flagellin gene (flaB): outer132f/905r (774 bp) and inner-220f/823r (604 bp) [35] (Table 3). The $25 \mu \mathrm{L}$ of PCR mixture contained 12.5 $\mu \mathrm{L}$ of DreamTaq Green PCR Master MIX (Thermo Scientific, Waltham, MA, USA), $10.5 \mu \mathrm{L}$ nuclease-free water, and $0.5 \mu \mathrm{L}$ of each primer $(10 \mu \mathrm{M})$, and $1 \mu \mathrm{L}$ of template DNA or $1 \mu \mathrm{L}$ of the outer PCR product for nested PCR. The thermal conditions of PCRs 
were as follows: 2 min at $94{ }^{\circ} \mathrm{C}$, by 40 cycles of $30 \mathrm{~s}$ at $94{ }^{\circ} \mathrm{C}, 30$ s at $50{ }^{\circ} \mathrm{C}\left(54{ }^{\circ} \mathrm{C}\right.$ for inner primers), $1 \mathrm{~min}$ at $72{ }^{\circ} \mathrm{C}$. Finally, an extension step of $1 \mathrm{~min}$ was performed at $72{ }^{\circ} \mathrm{C}$.

To identify the Borrelia species, the restriction fragment length polymorphism (RFLP) method was used [59]. The positive inner PCR products $(604 \mathrm{bp})$ were digested with restriction endonuclease HpyF3I (Fast Digest Tsp 509I, Thermo Scientific, Waltham, MA, USA) according to the manufacturer's instructions. Restriction fragments were separated on $3 \%$ agarose gel and stained with Midori Green dye (Nippon Genetics Europe GmbH, Düren, Germany). The obtained RFLP patterns enabled the identification of nine Borrelia species: B. garinii, B. afzelii, B. burgdorferi sensu stricto (s.s.), B. lusitaniae, B. valaisiana, B. bissetti, B. spielmanii, B. bavariensis and B. miyamotoi including the RF group of Borrelia $[35,59]$.

Table 3. Primer sets used for PCR amplification.

\begin{tabular}{|c|c|c|c|c|}
\hline $\begin{array}{l}\text { Primer } \\
\text { Name }\end{array}$ & Primer Sequence 5'-3' & $\begin{array}{l}\text { Product } \\
\text { Size }[b p]\end{array}$ & $\begin{array}{c}\text { Species } \\
\text { Gene }\end{array}$ & References \\
\hline $132 f$ & TGGTATGGGAGTTCTGG & \multirow{2}{*}{774} & \multirow{4}{*}{$\begin{array}{l}\text { Borrelia spp. } \\
\qquad \text { flaB }^{1}\end{array}$} & \multirow{4}{*}{ [35] } \\
\hline $905 r$ & TCTGTCATTGTAGCATCTTT & & & \\
\hline $220 f$ & CAGACAACAGAGGGAAAT & \multirow{2}{*}{604} & & \\
\hline $823 r$ & TCAAGTCTATTTTGGAAAGCACC & & & \\
\hline EHR521 & TGTAGGCGGTTCGGTAAGTTAAAG & \multirow{2}{*}{247} & \multirow{2}{*}{$\begin{array}{c}\text { A. } \\
\text { phagocytophilum } \\
\text { 16S rRNA }\end{array}$} & \multirow{2}{*}[60]{} \\
\hline EHR747 & GCACTCATCGTTTACAGCGTG & & & \\
\hline CS409 & CCTATGGCTATTATGCTTGC & \multirow{2}{*}{769} & \multirow{2}{*}{$\begin{array}{c}\text { Rickettsia spp. } \\
\operatorname{glt}^{2}{ }^{2}\end{array}$} & \multirow{2}{*}[61]{} \\
\hline Rp1258 & ATTGCAAAAAGTACAGTGAACA & & & \\
\hline
\end{tabular}

${ }_{1}^{1}$ flaB- flagellin gene, ${ }^{2}$ glt $A$ - citrate synthase gene.

\subsubsection{Anaplasma phagocytophilum}

A. phagocytophilum DNA was detected using the EHR521 and EHR747 primers [60] (Table 3) targeting a fragment of the $16 \mathrm{~S}$ rRNA gene $(247 \mathrm{bp})$ according to the protocol described by Michalski et al. [34].

\subsubsection{Rickettsia Species}

To detect and identify species of Rickettsia spp., primers CS409 and Rp1258 were used for the amplification of $769 \mathrm{bp}$ fragment of the gltA gene [61] (Table 3). The $25 \mu \mathrm{L}$ of PCR mixture contained $12.5 \mu \mathrm{L}$ of DreamTaq Green PCR Master MIX (Thermo Scientific, Waltham, MA, USA), $5.5 \mu \mathrm{L}$ nuclease-free water, $1 \mu \mathrm{L}$ of each primer $(10 \mu \mathrm{M})$ and $5 \mu \mathrm{L}$ of template DNA using the following PCR thermal conditions: 5 min at $95^{\circ} \mathrm{C}$, by 40 cycles of $30 \mathrm{~s}$ at $94{ }^{\circ} \mathrm{C}, 30 \mathrm{~s}$ at $55^{\circ} \mathrm{C}, 55 \mathrm{~s}$ at $72{ }^{\circ} \mathrm{C}$ and a final extension of $7 \mathrm{~min}$ at $72{ }^{\circ} \mathrm{C}$.

\subsubsection{PCRs}

All PCRs were carried out using a Mastercycler Nexus (Eppendorf, Hamburg, Germany). PCR products were visualized by electrophoresis on $1.5 \%$ agarose gel stained with Midori Green DNA dye (Nippon Genetics Europe GmbH, Düren, Germany). Each PCR analysis included negative (nuclease-free water instead of DNA) and positive control samples. The positive controls were a commercial sample of B. burgdorferi s.l. DNA (DNA Gdańsk, Poland) and samples of DNA positive for A. phagocytophilum and Rickettsia spp. obtained from ticks which were purified and confirmed by sequencing.

\subsection{DNA Sequencing and Data Analysis}

A randomly selected representative number of PCR products positive for Borrelia spirochetes $(n=3)$, A. phagocytophilum $(n=5)$ and Rickettsia spp. $(n=10)$ were purified using the Clean Up purification kit (A\&A Biotechnology, Gdynia, Poland) according to the manufacturer's protocol and bidirectionally sequenced at Macrogen Europe (Amsterdam, The Netherlands). The obtained nucleotide sequences were edited in BioEdit software [62] 
and compared with data registered in the GenBank database (http:/ /www.ncbi.nih.gov/ Genbank/index.html, accessed on: 11 February 2021) using the BLAST-NCBI program (http:/ / www.ncbi.nlm.nih.gov/BLAST/, accessed on: 9 April 2021). Consensus sequences of the fragment of Borrelia flaB gene were deposited in the GenBank database and registered under the accession numbers: MW595226-595228, for the A. phagocytophilum 16S RNA gene: MW591521-591525 and the Rickettsia gltA fragment gene: MW595229-595238.

Representative Borrelia and Rickettsia sequences obtained in this study and the most similar sequences chosen from GenBank were used in phylogenetic analysis. The phylogram was constructed using a method based on the neighbor-joining method and the Maximum Composite Likelihood as a distance method. The topology of the phylogram was evaluated using the bootstrap method with 1000 replicates. Phylogenetic analysis was conducted using MEGA X software (Penn. State University, Philadelphia, PA, USA).

\subsection{Statistical Analysis}

Each tick was analyzed individually. The prevalence was expressed using percentages. A statistical analysis of the results was performed using a two-sided Fisher's exact test (Prism 6 program, GraphPad Software, San Diego, CA, USA). The prevalence of pathogens was calculated with $95 \%$ confidence intervals $(95 \% \mathrm{CI}$ ) using the "exact" interval by Clopper and Pearson. A Chi-square test $\left(\chi^{2}\right)$ was used to check whether there was a relationship between variables, i.e., a prevalence of pathogens in both tested tick species and between subregions. Pearson's correlation coefficient $(r)$ was determined to establish the association of double co-infections with the subregions. Values of $p<0.05$ were considered statistically significant.

\section{Conclusions}

Pathogens of the complex of B. burgdorferi s.l. (B. afzelii, B. garinii, B. lusitaniae), B. miyamotoi relapsing fever spirochete, $A$. phagocytophilum, and Rickettsia spp. have been detected in ticks removed from wild even-toed ungulates in north-eastern Poland. The low level of spirochete infections among ticks removed from wild mammals can be explained by the loss of Borrelia infections during feeding. The relatively high infestation level of ticks feeding on wild mammals, especially cervids, and infected with A. phagocytophilum and spotted fever rickettsiae group, may indicate that these animals are important reservoirs of both pathogens, contributing to their circulation in nature and are a potential source of infections for humans through ticks as vectors. This study illustrates that wild ungulates with heavy tick exposure in north-eastern Poland can be infected more frequently with single than multiple tick-borne pathogens of potential clinical importance.

Author Contributions: Conceptualization, M.M.M. and M.D.; methodology, M.M.M., M.S., K.K. and M.D.; writing—original draft preparation, M.D., K.K., M.M.M. and M.S.; validation, formal analysis, and review, M.D., M.M.M., K.K. and M.S.; supervision, M.D. All authors have read and agreed to the published version of the manuscript.

Funding: This study was partially supported by the Marshal's Office of the Warmia-Masuria Province in Olsztyn, grant No.: 1 UWM/2018, DOŚ.11.2018.

Institutional Review Board Statement: Not applicable.

Informed Consent Statement: Not applicable.

Data Availability Statement: The data presented in this study are contained within the article.

Acknowledgments: The authors would like to thank Jarosław Szecówka, for help in editing the manuscript and Kazimierz Zalewski for contacts with hunters and providing research material.

Conflicts of Interest: The authors declare no conflict of interest. The funders had no role in the design of the study; in the collection, analyses, or interpretation of data; in the writing of the manuscript or in the decision to publish the results. 


\section{References}

1. Viana, M.; Mancy, R.; Biek, R.; Cleaveland, S.; Cross, P.C.; Lloyd-Smith, J.O.; Haydon, D.T. Assembling evidence for identifying reservoirs of infection. Trends Ecol. Evol. 2014, 29, 270-279. [CrossRef]

2. Chastagner, A.; Pion, A.; Verheyden, H.; Lourtet, B.; Cargnelutti, B.; Picot, D.; Poux, V.; Bard, É.; Plantard, O.; McCoy, K.D.; et al. Host specificity, pathogen exposure, and superinfections impact the distribution of Anaplasma phagocytophilum genotypes in ticks, roe deer, and livestock in a fragmented agricultural landscape. Infect. Genet. Evol. 2017, 55, 31-44. [CrossRef]

3. Hofmeester, T.R.; Sprong, H.; Jansen, P.A.; Prins, H.H.T.; Van Wieren, S.E. Deer presence rather than abundance determines the population density of the sheep tick, Ixodes ricinus, in Dutch forests. Parasites Vectors 2017, 10, 1-8. [CrossRef] [PubMed]

4. Jaenson, T.G.T.; Petersson, E.H.; Jaenson, D.G.E.; Kindberg, J.; Pettersson, J.H.O.; Hjertqvist, M.; Medlock, J.M.; Bengtsson, H. The importance of wildlife in the ecology and epidemiology of the TBE virus in Sweden: Incidence of human TBE correlates with abundance of deer and hares. Parasites Vectors 2018, 11, 1-18. [CrossRef]

5. Tavernier, P.; Sys, S.U.; De Clercq, K.; De Leeuw, I.; Caij, A.B.; De Baere, M.; De Regge, N.; Fretin, D.; Roupie, V.; Govaerts, M.; et al. Serologic screening for 13 infectious agents in roe deer (Capreolus capreolus) in Flanders. Infect. Ecol. Epidemiol. $2015,5,29862$. [CrossRef]

6. Seo, M.G.; Kwon, O.D.; Kwak, D. Molecular identification of Borrelia afzelii from ticks parasitizing domestic and wild animals in South Korea. Microorganisms 2020, 8, 649. [CrossRef]

7. Kim, B.J.; Kim, H.; Won, S.; Kim, H.C.; Chong, S.T.; Klein, T.A.; Kim, K.G.; Seo, H.Y.; Chae, J.S. Ticks collected from wild and domestic animals and natural habitats in the Republic of Korea. Korean J. Parasitol. 2014, 52, 281-285. [CrossRef]

8. Skotarczak, B. The role of companion animals in the environmental circulation of tick-borne bacterial pathogens. Ann. Agric. Environ. Med. 2018, 25, 473-480. [CrossRef] [PubMed]

9. Buczek, W.; Koman-Iżko, A.; Buczek, A.M.; Buczek, A.; Bartosik, K.; Kulina, D.; Ciura, D. Spotted fever group rickettsiae transmitted bydermacentor ticks and determinants of their spread in europe. Ann. Agric. Environ. Med. 2020, $27,505-511$. [CrossRef] [PubMed]

10. Kubiak, K.; Szczotko, M.; Dmitryjuk, M. Borrelia miyamotoi-An emerging human tick-borne pathogen in europe. Microorganisms 2021, 9, 154. [CrossRef]

11. Kubiak, K.; Dziekońska-Rynko, J.; Szymańska, H.; Kubiak, D.; Dmitryjuk, M.; Dzika, E. Questing Ixodes ricinus ticks (Acari, Ixodidae) as a vector of Borrelia burgdorferi sensu lato and Borrelia miyamotoi in an urban area of north-eastern Poland. Exp. Appl. Acarol. 2019, 78, 113-126. [CrossRef]

12. Rizzoli, A.; Hauffe, H.C.; Carpi, G.; Vourc'h, G.I.; Neteler, M.; Rosà, R. Lyme borreliosis in Europe. Eurosurveillance 2011, 16, 1-8. [CrossRef]

13. Dzieggiel, B.; Adaszek, Ł.; Winiarczyk, S. Wild animals as reservoirs of Anaplasma phagocytophilum for humans. Przegl. Epidemiol. 2016, 70, 428-435.

14. Teodorowski, O.; Radzki, R.; Kalinowski, M.; Winiarczyk, S.; Bocanegra, I.G.; Winiarczyk, D.; Adaszek, L. Moleculardetection of Anaplasma phagocytophilum in roe deer (Capreolus capreolus) in eastern Poland. Ann. Agric. Environ. Med. 2020, 27, 702-705. [CrossRef]

15. Skotarczak, B.; Adamska, M.; Sawczuk, M.; Maciejewska, A.; Wodecka, B.; Rymaszewska, A. Coexistence of tick-borne pathogens in game animals and ticks in western Poland. Vet. Med. 2008, 53, 668-675. [CrossRef]

16. Overzier, E.; Pfister, K.; Herb, I.; Mahling, M.; Böck, G.; Silaghi, C. Detection of tick-borne pathogens in roe deer (Capreolus capreolus), in questing ticks (Ixodes ricinus), and in ticks infesting roe deer in southern Germany. Ticks Tick. Borne. Dis. 2013, 4, 320-328. [CrossRef]

17. Kauffmann, M.; Rehbein, S.; Hamel, D.; Lutz, W.; Heddergott, M.; Pfister, K.; Silaghi, C. Anaplasma phagocytophilum and Babesia spp. in roe deer (Capreolus capreolus), fallow deer (Dama dama) and mouflon (Ovis musimon) in Germany. Mol. Cell. Probes 2017, 31, 46-54. [CrossRef] [PubMed]

18. Hornok, S.; Sugár, L.; Fernández de Mera, I.G.; de la Fuente, J.; Horváth, G.; Kovács, T.; Micsutka, A.; Gönczi, E.; Flaisz, B.; Takács, N.; et al. Tick- and fly-borne bacteria in ungulates: The prevalence of Anaplasma phagocytophilum, haemoplasmas and rickettsiae in water buffalo and deer species in Central Europe, Hungary. BMC Vet. Res. 2018, 14, 1-7. [CrossRef] [PubMed]

19. Kazimírová, M.; Hamšíková, Z.; Špitalská, E.; Minichová, L.; Mahríková, L.; Caban, R.; Sprong, H.; Fonville, M.; Schnittger, L.; Kocianová, E. Diverse tick-borne microorganisms identified in free-living ungulates in Slovakia. Parasites Vectors 2018, 11, 1-18. [CrossRef]

20. Remesar, S.; Díaz, P.; Prieto, A.; García-Dios, D.; Fernández, G.; López, C.M.; Panadero, R.; Díez-Baños, P.; Morrondo, P. Prevalence and molecular characterization of Anaplasma phagocytophilum in roe deer (Capreolus capreolus) from Spain. Ticks Tick. Borne. Dis. 2020, 11, 101351. [CrossRef]

21. Adamska, M. The role of different species of wild ungulates and Ixodes ricinus ticks in the circulation of genetic variants of Anaplasma phagocytophilum in a forest biotope in north-western Poland. Ticks Tick. Borne. Dis. 2020, 11. [CrossRef]

22. Piotrowski, M.; Rymaszewska, A. Expansion of tick-borne rickettsioses in the world. Microorganisms 2020, 8, 1906. [CrossRef]

23. Kowalec, M.; Szewczyk, T.; Welc-Falęciak, R.; Siński, E.; Karbowiak, G.; Bajer, A. Rickettsiales occurrence and co-occurrence in Ixodes ricinus ticks in natural and urban Areas. Microb. Ecol. 2019, 77, 890-904. [CrossRef] [PubMed]

24. Platonov, A.E.; Karan, L.S.; Kolyasnikova, N.M.; Makhneva, N.A.; Toporkova, M.G.; Maleev, V.V.; Fish, D.; Krause, P.J. Humans infected with relapsing fever spirochete Borrelia miyamotoi, Russia. Emerg. Infect. Dis. 2011, 17, 1816-1823. [CrossRef] 
25. Takano, A.; Toyomane, K.; Konnai, S.; Ohashi, K.; Nakao, M.; Ito, T.; Andoh, M.; Maeda, K.; Watarai, M.; Sato, K.; et al. Tick surveillance for relapsing fever spirochete Borrelia miyamotoi in Hokkaido, Japan. PLoS ONE 2014, 9, e104532. [CrossRef]

26. Vor, T.; Kiffner, C.; Hagedorn, P.; Niedrig, M.; Rühe, F. Tick burden on European roe deer (Capreolus capreolus). Exp. Appl. Acarol. 2010, 51, 405-417. [CrossRef] [PubMed]

27. Zając, Z.; Woźniak, A.; Kulisz, J. Infestation of dairy cows by ticks Dermacentor reticulatus (Fabricius, 1794) and Ixodes ricinus (Linnaeus, 1758) in eastern Poland. Ann. Parasitol. 2020, 66, 87-96. [CrossRef]

28. Földvári, G.; Široký, P.; Szekeres, S.; Majoros, G.; Sprong, H. Dermacentor reticulatus: A vector on the rise. Parasites Vectors 2016, 9 , 1-29. [CrossRef]

29. Kubiak, K.; Sielawa, H.; Dziekońska-Rynko, J.; Kubiak, D.; Rydzewska, M.; Dzika, E. Dermacentor reticulatus ticks (Acari: Ixodidae) distribution in north-eastern Poland: An endemic area of tick-borne diseases. Exp. Appl. Acarol. 2018, 75, 289-298. [CrossRef]

30. Pacilly, F.C.A.; Benning, M.E.; Jacobs, F.; Leidekker, J.; Sprong, H.; Van Wieren, S.E.; Takken, W. Blood feeding on large grazers affects the transmission of Borrelia burgdorferi sensu lato by Ixodes ricinus. Ticks Tick. Borne. Dis. 2014, 5, 810-817. [CrossRef] [PubMed]

31. Piksa, K.; Stańczak, J.; Biernat, B.; Górz, A.; Nowak-Chmura, M.; Siuda, K. Detection of Borrelia burgdorferi sensu lato and spotted fever group rickettsiae in hard ticks (Acari, Ixodidae) parasitizing bats in Poland. Parasitol. Res. 2016, 115, 1727-1731. [CrossRef]

32. Díaz, P.; Remesar, S.; Venzal, J.M.; Vázquez-López, M.E.; Fernández, G.; López, C.; Díez-Baños, P.; Morrondo, P.; Panadero, R. Occurrence of Borrelia and Borreliella species in Ixodes ricinus collected from roe deer in northwestern Spain. Med. Vet. Entomol. 2019, 33, 427-430. [CrossRef] [PubMed]

33. Nakayama, S.; Kobayashi, T.; Nakamura, A.; Yoshitomi, H.; Song, Y.; Ashizuka, Y. Detection of Borrelia DNA in tick species collected from vegetation and wild animals in Fukuoka, Japan. Jpn. J. Infect. Dis. 2020, 73, 61-64. [CrossRef] [PubMed]

34. Michalski, M.M.; Kubiak, K.; Szczotko, M.; Chajęcka, M.; Dmitryjuk, M. Molecular detection of Borrelia burgdorferi sensu lato and Anaplasma phagocytophilum in ticks collected from dogs in urban areas of North-Eastern Poland. Pathogens 2020, 9, 455. [CrossRef] [PubMed]

35. Wodecka, B.; Leońska, A.; Skotarczak, B. A comparative analysis of molecular markers for the detection and identification of Borrelia spirochaetes in Ixodes ricinus. J. Med. Microbiol. 2010, 59, 309-314. [CrossRef] [PubMed]

36. Kiewra, D.; Stańczak, J.; Richter, M. Ixodes ricinus ticks (Acari, Ixodidae) as a vector of Borrelia burgdorferi sensu lato and Borrelia miyamotoi in Lower Silesia, Poland-Preliminary study. Ticks Tick. Borne. Dis. 2014, 5, 892-897. [CrossRef] [PubMed]

37. Kowalec, M.; Szewczyk, T.; Welc-Falęciak, R.; Siński, E.; Karbowiak, G.; Bajer, A. Ticks and the city-Are there any differences between city parks and natural forests in terms of tick abundance and prevalence of spirochaetes? Parasites Vectors 2017, 10, 1-19. [CrossRef]

38. Chrudimská, T.; Chrudimský, T.; Golovchenko, M.; Rudenko, N.; Grubhoffer, L. New defensins from hard and soft ticks: Similarities, differences, and phylogenetic analyses. Vet. Parasitol. 2010, 167, 298-303. [CrossRef]

39. Michalik, J.; Stańczak, J.; Racewicz, M.; Cieniuch, S.; Sikora, B.; Szubert-Kruszyńska, A.; Grochowalska, R. Molecular evidence of Anaplasma phagocytophilum infection in wild cervids and feeding Ixodes ricinus ticks from west-central Poland. Clin. Microbiol. Infect. 2009, 15, 81-83. [CrossRef]

40. Adamska, M.; Skotarczak, B. Wild game as a reservoir of Anaplasma phagocytophilum in north-western Poland. Wiadomości Parazytol. 2007, 53, 103-107.

41. Levytska, V.A.; Mushinsky, A.B.; Zubrikova, D.; Blanarova, L.; Długosz, E.; Vichova, B.; Slivinska, K.A.; Gajewski, Z.; Gizinski, S.; Liu, S.; et al. Detection of pathogens in Ixodid ticks collected from animals and vegetation in five regions of Ukraine. Ticks Tick. Borne. Dis. 2021, 12. [CrossRef] [PubMed]

42. Veronesi, F.; Galuppi, R.; Tampieri, M.P.; Bonoli, C.; Mammoli, R.; Fioretti, D.P. Prevalence of Anaplasma phagocytophilum in fallow deer (Dama dama) and feeding ticks from an Italy preserve. Res. Vet. Sci. 2011, 90, 40-43. [CrossRef] [PubMed]

43. Di Domenico, M.; Pascucci, I.; Curini, V.; Cocco, A.; Dall'Acqua, F.; Pompilii, C.; Cammà, C. Detection of Anaplasma phagocytophilum genotypes that are potentially virulent for human in wild ruminants and Ixodes ricinus in Central Italy. Ticks Tick. Borne. Dis. 2016, 7, 782-787. [CrossRef]

44. Grassi, L.; Franzo, G.; Martini, M.; Mondin, A.; Cassini, R.; Drigo, M.; Pasotto, D.; Vidorin, E.; Menandro, M.L. Ecotyping of Anaplasma Phagocytophilum from wild ungulates and ticks shows circulation of zoonotic strains in northeastern Italy. Animals 2021, 11, 310. [CrossRef] [PubMed]

45. Chmielewski, T.; Podsiadly, E.; Karbowiak, G.; Tylewska-Wierzbanowska, S. Rickettsia spp. in ticks, Poland. Emerg. Infect. Dis. 2009, 15, 486-488. [CrossRef]

46. Biernat, B.; Stańczak, J.; Michalik, J.; Sikora, B.; Wierzbicka, A. Prevalence of infection with Rickettsia helvetica in Ixodes ricinus ticks feeding on non-rickettsiemic rodent hosts in sylvatic habitats of west-central Poland. Ticks Tick. Borne. Dis. 2016, 7, 135-141. [CrossRef]

47. Skotarczak, B.; Wodecka, B.; Rymaszewska, A.; Adamska, M. Molecular evidence for bacterial pathogens in Ixodes ricinus ticks infesting Shetland ponies. Exp. Appl. Acarol. 2016, 69, 179-189. [CrossRef]

48. Wójcik-Fatla, A.; Cisak, E.; Zajac, V.; Sroka, J.; Sawczyn, A.; Dutkiewicz, J. Study on tick-borne rickettsiae in eastern Poland. I. prevalence in Dermacentor reticulatus (Acari: Amblyommidae). Ann. Agric. Environ. Med. 2013, 20, $276-279$.

49. Mierzejewska, E.J.; Pawełczyk, A.; Radkowski, M.; Welc-Falęciak, R.; Bajer, A. Pathogens vectored by the tick, Dermacentor reticulatus, in endemic regions and zones of expansion in Poland. Parasites Vectors 2015, 8. [CrossRef] [PubMed] 
50. Zając, V.; Wójcik-Fatla, A.; Sawczyn, A.; Cisak, E.; Sroka, J.; Kloc, A.; Zając, Z.; Buczek, A.; Dutkiewicz, J.; Bartosik, K. Prevalence of infections and co-infections with 6 pathogens in Dermacentor reticulatus ticks collected in eastern Poland. Ann. Agric. Environ. Med. 2017, 24, 26-32. [CrossRef]

51. Stańczak, J.; Biernat, B.; Racewicz, M.; Zalewska, M.; Matyjasek, A. Prevalence of different Rickettsia spp. in Ixodes ricinus and Dermacentor reticulatus ticks (Acari: Ixodidae) in north-eastern Poland. Ticks Tick. Borne. Dis. 2018, 9, 427-434. [CrossRef] [PubMed]

52. Dwużnik, D.; Mierzejewska, E.J.; Drabik, P.; Kloch, A.; Alsarraf, M.; Behnke, J.M.; Bajer, A. The role of juvenile Dermacentor reticulatus ticks as vectors of microorganisms and the problem of 'meal contamination'. Exp. Appl. Acarol. 2019, 78, 181-202. [CrossRef] [PubMed]

53. Zając, V.; Sroka, J.; Sawczyn-Domańska, A.; Kloc, A.; Wójcik-Fatla, A. Prevalence of spotted fever group rickettsiae in Poland. Environ. Med. 2019, 22, 13-19. [CrossRef]

54. Stańczak, J. Detection of spotted fever group (SFG) rickettsiae in Dermacentor reticulatus (Acari: Ixodidae) in Poland. Int. J. Med. Microbiol. 2006, 296, 144-148. [CrossRef]

55. Stańczak, J.; Racewicz, M.; Michalik, J.; Cieniuch, S.; Sikora, B.; Skoracki, M. Prevalence of infection with Rickettsia helvetica in feeding ticks and their hosts in western Poland. Clin. Microbiol. Infect. 2009, 15, 328-329. [CrossRef]

56. Król, N.; Obiegala, A.; Pfeffer, M.; Lonc, E.; Kiewra, D. Detection of selected pathogens in ticks collected from cats and dogs in the Wrocław Agglomeration, South-West Poland. Parasites Vectors 2016, 9, 1-7. [CrossRef]

57. Dautel, H.; Dippel, C.; Oehme, R.; Hartelt, K.; Schettler, E. Evidence for an increased geographical distribution of Dermacentor reticulatus in Germany and detection of Rickettsia sp. RpA4. Int. J. Med. Microbiol. 2006, 296, 149-156. [CrossRef]

58. Nowak-Chmura, M. Fauna kleszczy (Ixodida) Europy Środkowej; Wydawnictwo Naukowe Uniwersytetu Pedagogicznego: Kraków, Poland, 2013.

59. Wodecka, B. flaB gene as a molecular marker for distinct identification of Borrelia species in environmental samples by the PCR-restriction fragment length polymorphism method. Appl. Environ. Microbiol. 2011, 77, 7088-7092. [CrossRef]

60. Pancholi, P.; Kolbert, C.P.; Mitchell, P.D.; Reed, K.D.; Dumler, J.S.; Bakken, J.S.; Telford, S.R., III; Persing, D.H. Ixodes dammini as a potential vector of human granulocytic ehrlichiosis. J. Infect. Dis. 1995, 172, 1007-1012. [CrossRef]

61. Roux, V.; Rydkina, E.; Eremeeva, M.; Raoult, D. Citrate synthase gene comparison, a new tool for phylogenetic analysis, and its application for the rickettsiae. Int. J. Syst. Bacteriol. 1997, 47, 252-261. [CrossRef]

62. Hall, T.A. BioEdit: A User-Friendly Biological Sequence Alignment Editor and Analysis Program for Windows 95/98/NTe. Nucleic Acids Symp. Ser. 1999, 41, 95-98. 